\title{
Instructional Leadership Strategy Principal in Improving the Quality of Graduates of Public Vocational School 1 Barabai
}

\author{
Metroyadi, Ainun Jariah \\ Master of Education Management Program, Faculty of Teacher Training and Education \\ Universitas Lambung Mangkurat \\ Banjarmasin, Indonesia \\ Metroyadi59@gmail.com, ainun.akuntansi@gmail.com
}

\begin{abstract}
This study aimed to describe the application of principals' leadership instructors to improve the ability of graduates of Public Vocational School 1 Barabai 1. This study used a qualitative method. Data collection techniques were interviews, data collection techniques through interviews, and documentation. The technique of analyzing data was through data reduction on all existing data. To check the validity of the data, triangulation, and triangulation of the technique was carried out. Based on the results of the analysis, it was found that the principal's leadership was completed in planning activities, teaching and learning, and learning evaluation to improve the process and achievement of student learning. Instructional Leadership of Principals in Public Vocational School 1 Barabai is in a very good category.
\end{abstract}

Keywords - the leadership instructional, graduated competency, teacher's competency

\section{INTRODUCTION}

Education is an important thing to note, and education is the main factor in the formation of the human person. Therefore, the world of education must strive to find and find new breakthroughs by using appropriate management concepts in achieving educational goals. A quality education can be measured from its position to contribute to the intellectual life of the nation.

As disclosed the national education goals stated in the National Education System Law No. 20 of 2003 article 3 states that: "National education functions to develop capabilities and shape dignified national character and civilization in order to educate the nation's life, aiming at developing potential students to become human beings who believe and fear God Almighty, noble, healthy, knowledgeable, capable, creative, independent, and a democratic and responsible citizen. "

A school is a place to carry out education as well as being responsible for realizing national education goals. In facing the challenges of revolution 4.0, SMK must continue to develop dynamically and be able to organize competency-based education. It takes a high commitment so that Vocational Schools are able to produce graduates who are competent in their competency skills, as productive and professional workforce recognized nationally and internationally.
Vocational School is a formal education institution that is expected to create young entrepreneurs, workers who are competent in their fields. For this reason, it is necessary to have an effective learning process in accordance with the curriculum and SKKNI, the performance of educators must also be appropriate, and leadership that is in accordance with the expected goals.

Competency certificates are very important for students who will graduate from Vocational School, as proof of their competency. Competency testing is carried out through a Professional Certification Agency (LSP) formed in Vocational Schools that has been licensed by the National Professional Certification Agency (BNSP). Through that, the students in their competency tests are in accordance with SKKNI which is in accordance with the competency skills of students in Vocational Schools.

Competency test through LSP P1, students are required to be competent in seven competency units (applying professional practice principles in work, applying health and safety practices in the workplace, processing journal entries, processing ledgers, preparing financial reports, operating processing program packages numbers/spreadsheets, and operate accounting computer applications) on SKKNI Junior Accounting Technicians for Vocational High Schools for QUALIFICATION II, so that eventually students get competency certificates from BNSP. So, with this certificate students are recognized as competent in the scheme.

The results of the competency test were evaluated by the school principal with the teaching staff, why many students were not yet competent. The results of the meeting evaluated the teaching and learning process carried out and also in terms of the teaching staff. From the evaluation results, there are educators who do not have teaching competence optimally, there are some educators who still lack the skills to apply teaching methods, and not many educators have effective and efficient teaching performance in carrying out tasks and responsibilities of educators who are still lacking in learning evaluation. This problem indicates that the teacher's teaching performance is still not optimal.

This global phenomenon is also directly proportional to what happened at Public Vocational School 1 Barabai. The 
researcher conducted a study of the results of the competency test on accounting skills competency students with a competency test in the Junior Accounting Technician scheme showing that many students were not yet competent in this Junior Accounting Technician scheme.

The principal also has many daily work functions in the school to improve the teaching and learning process well. More operationally, the principal's principal tasks include activities to explore and utilize all school resources in an integrated manner in the framework of achieving school goals effectively and efficiently; this is also called instructional leadership.

Instructional leadership fosters teaching direction and direction, fosters learning communities, shares the same in making decisions, maintaining and maintaining basic cases, benefits and optimizing time, supporting the development of continuous staff, designing original resources to support school programs.

The leadership style of principals in carrying out their duties and responsibilities is very influential on teacher performance because successful leaders are leaders who are able to manage and empower the resources that are available in schools effectively and efficiently to achieve school goals or educational goals.

With instructional leadership, it is expected that teacher performance will increase, which will ultimately increase student competence. The competency of students will be seen from the competency certificate obtained by students after being declared competent in the competency test through LSP.

Given the importance of instructional leadership in the work process of principals so that they can improve teacher performance and prove how much influence the principals 'instructional leadership has on teacher performance, researchers want to conduct research by taking the title "Principal Instructional Leadership Strategies in Increasing Graduates' Competencies Arabic State Vocational School "The purpose of this study is to describe the application of Principal Executive Leadership to Competencies of Graduates of Public Vocational School 1 Barabai.

\section{LITERATURE REVIEW}

The concept of instructional leadership or learning leadership is focused on improving academic quality, not on the busy handling of school administration such as buildings, facilities or financial facilities, all of their busyness is intended to influence school academic activities related to learning [1]. Ref [2] defines learning leadership is leadership that focuses directly on the teaching and learning process, increasing student achievement, curriculum and assessment, and developing learning programs. Instructional leadership is leadership that focuses on the process and learning outcomes of students through empowering teachers professionally.

The main purpose of learning leadership is to provide excellent service to all students so that they are able to develop their basic quality potential and instrumental qualities to face an unknown future and are filled with very turbulent challenges. Instrumental quality includes mastery of science and technology and art. Science can be classified into soft science (sociology, politics, economics, education, anthropology, and the like).

Learning leadership contributes very significantly to improving student learning achievement. Learning leadership is able to provide encouragement and direction to the school community to improve student learning achievement and be able to focus the activities of its citizens towards achieving school vision, mission, and goals.

The principal has a number of roles that must be played together, including among others educators, managers, administrators, supervisors, motivators, entrepreneurs, and leaders. The role of the principal as a leader (leader) and specifically as an instructional leader, lacks the appropriate portion. The principal is preoccupied with routine administrative work, meetings, and other activities that are non-academic in nature, so that time to study curriculum renewal/innovation, teaching and learning processes, and assessment of student learning outcomes is not getting enough attention. In fact, the last three things are very closely related to improving the quality of the teaching and learning process, which in turn, the quality of the teaching and learning process is very influential on improving student quality and overall school quality. For this reason, it is appropriate for the learning leadership role to obtain a greater portion of time than other roles. Other roles are not important, but learning leadership roles must be the most important.

\section{METHODS}

This research used the qualitative method. data collection techniques were through interviews, observation, and documentation. interview with the Head of Public Vocational School 1 Barabai and Public Vocational School 1 Barabai Management Board. Data collected about the description of instructional leadership of the head of Public Vocational School 1 Barabai. The technique of analyzing data was through data reduction on all existing data. Triangulation of sources and triangulation of the technique were carried out to check the validity of the data in fulfilling the credibility criteria, and transfiguration of a study.

\section{RESULT AND DISCUSSION}

Data were collected through interviews with the Head of 1 Barabai State Vocational School and Management of Public Vocational School 1 Barabai LSP. The results of the interviews were checked by direct observation of the activities of the Head of Public Vocational School 1 Barabai in instructional leadership activities.

Understanding of the Head of Public Vocational School 1 Barabai towards the Definition of Instructional Leadership can be concluded that instructional leadership is the implementation assistance of the teaching and learning process that includes activities: planning, implementing and evaluating learning in order to improve student learning processes and outcomes. The results of direct observation indicate that the principal is mentoring by first socializing the preparation of the Lesson Plan (RPP), giving examples of how to make a good 
lesson plan, and assigning each teacher to make a lesson plan. The lesson plan that was made by the teacher was then examined, and the teacher had not revised it well until it was finally signed by the school principal. RPP of all teachers has been well documented in the RPP specific map.

The opinion of the Head of Public Vocational School 1 Barabai about the Purpose and Benefits of Instructional Leadership can be concluded that the purpose of instructional leadership is the realization of improving the quality of the process and student learning outcomes continuously. The benefits of instructional leadership are: (1) increasing student learning outcomes; and (2) increasing teacher performance. The results of participatory observations indicate that the daily test scores, school examinations, and national examinations from year to year have been continuously increasing. Orderly administrative teacher in completing lesson plans for all subjects. Teacher teaching motivation and student learning motivation increase. Teacher performance and satisfaction increases. Monev of learning takes place in a private manner. Documentation data on student learning outcomes increase continuously.

The opinion of the Head of Public Vocational School 1 Barabai on Effective Instructional Leadership Indicators concluded that the indicators of effective learning leadership are: (1) formulating concepts and implementation strategies; (2) set targets to be achieved; (3) consistent with improving quality; and (4) continue to make continuous improvements.

The Instructional Leadership Strategy in 1 Barabai State Vocational School concluded that instructional leadership strategies according to the Head of Barabai State Vocational High School were: (1) much discussion with teachers about improving the quality of learning; and (2) accompanying the teacher.

Practical Ways of Head of Barabai State Vocational School 1 Implement Instructional Leadership concluded that practical ways of conducting instructional leadership are: (1) implementing learning administration preparation; (2) carry out monitoring and evaluation of the classroom learning process periodically, and (3) provide recommendations for teachers who are monitored for improvement.

The leadership of the Barabai 1 State Vocational High School is expected to use instructional leadership that is in line with reference [3] by developing a more operational learning leadership concept with seven steps of leadership learning complete with indicators such as the following: evaluating the progress of learning objectives, 3) applying formative procedures that are good at evaluating learning programs, 4) communicating the school's vision and mission to staff, 5) conditioning staff to achieve high professional ideals, 6) involving yourself teaching directly in class ; 7) develop the professional skills of teachers, 8) make schedules, plans, or facilitate various meetings (planning, problem solving, decision making, or in-service training) teachers who discuss learning issues, and 9) Be positive towards students, staff, and parents of students.

\section{A. Setting Learning Objectives}

The headmaster must be able to determine and set goals for school development, in the implementation of the headmaster of the Public Vocational School 1 Barabai in this matter always involving teachers in developing and implementing learning goals and objectives and the headmaster also refers to the curriculum set by the government in developing learning. This is in line with the opinion of reference [4] regarding the purpose is very important in teaching, because teaching is an intentional and reasoned action. In addition, the school principal also ensures the activity and evaluates the progress towards achieving the learning objectives.

\section{B. Becoming a resource for staff}

The principal at Public Vocational School 1 Barabai in implementing it always works with the teacher to improve the learning program in the classroom according to the needs of the students. The work culture is always applied by school principals to cooperate with teachers in improving the quality of learning. This is in line with reference [5] the influence of work culture in organizations if implemented in schools is fun and supports the implementation of daily tasks so that these conditions will contribute significantly to the realization of improving the quality of learning.

\section{Creating a Conducive School Culture and Climate for Learning}

In general, the Principal in Barabai 1 Public Vocational School has been considered very good in creating inclusive classes that give the impression that in it all students can learn and the principal provides time for students to study longer. Furthermore, the Head always gives direction to the teacher in each meeting so that the teacher always behaves positively. In addition, the principal makes policies related to student learning progress (homework, assessment, monitoring learning progress, remediation, reports on learning outcomes, increase/stay). The principal leadership instructional pattern of Public Vocational School 1 Barabai is implemented by providing clear information to the teacher. Ref [6] with clear and transparent information is very important for schools in developing collaboration with the teacher.

\section{Communicating the Vision and Mission of the School to the Staff}

In line with reference [7], the school principal socialized and instilled the contents and meaning of the school's vision well. The principal is also able to establish habits of sharing opinions in formulating the vision and mission of his school, and he always maintains that the school's vision and mission that have been agreed upon by the school community are thriving in its implementation. The headmaster of Public Vocational School 1 Barabai has been very good at making systematic two-way communication with staff about school goals and objectives.

\section{E. Conditioning Staff to Achieve High Professional Ideas}

General description School principals at Barabai 1 Public Vocational School are very good at engaging in teaching 
directly in class and helping teachers in pursuing their professional will related to school learning and watching whether their wishes are realized or not. In addition, principals always involve themselves in preparing class observations regularly, both informally and formally. This agrees with reference [7] that in managing education personnel, principals should be able to facilitate and provide broad opportunities for teachers to be able to carry out professional development activities through various educational and training activities, both those carried out in schools and out of school. Even the Principal at Barabai 1 Public Vocational School is very good at conducting in-depth evaluations, is responsible, directs, and provides recommendations for personal and professional development in accordance with the individual needs of the teacher.

\section{F. Developing Teacher's Professional Capabilities}

Based on the results of the analysis, the principal at Barabai State Vocational School 1 always helps make schedules, plans, and facilitates various meeting activities (planning, problem solving, decision making, or in-service training) teachers who discuss learning issues, in addition the principal is always giving the teacher the chance to take part in training on collaboration, joint decision making, coaching, mentoring, developing curriculum, and presentations and providing motivation and resources to the teacher to participate in professional development activities very well. The above is in agreement with reference [7] arguing that: "Principals as managers have the task of developing personnel performance, especially improving teacher professional competence."

\section{G. Being Positive towards Students, Staff, and Parents}

The head of Barabai 1 Public Vocational School always serves students and communicates with students in various lives very well. In addition, principals also communicate with staff openly and respect various differences and always pay attention to the problems of students, teachers, and staff and involve themselves in solving problems that appear to have been very good. Agree with reference [7] namely: "one's leadership is closely related to the personality and personality of the principal as a leader will be reflected in the following characteristics: (1) honest; (2) confidence; (3) responsibility;
(4) dare to take risks and decisions; (5) big soul; (6) stable emotions, and (7) role models. "

\section{CONCLUSION}

Instructional Leadership of Principals in Barabai 1 Public Vocational School is in a very good category, based on 7 aspects of effective instructional leadership. But when looking at each part of the indicator, the tendency for lower values in indicators conditions staff to achieve high professional ideals with sub-indicators in engaging themselves in the preparation of classroom observations. So there needs to be an increase in the participation of principals in carrying out classroom observations, the principal knows the real conditions of the class.

\section{ACKNOWLEDGEMENT}

The author would like to thank the head of Barabai 1 State Vocational High School for giving an explanation of instructional leadership. The author also thanked the board of LSP 1 Barabai Vocational High School for providing information on competency testing through Public Vocational School 1 Barabai LSP in the Junior Accounting Technician Scheme.

\section{REFERENCES}

[1] D. Suhardan, Supervisi profesional, Bandung : Alfabeta, 2010.

[2] T. J. Sergiovanni, The Principalship: a reflective practice perspective. Texas: Pearson education, 2009

[3] E. K. McEwan, 7 Steps to effective instructional leadership. California: Corwin Press, 2002.

[4] L. W. Anderson, and D. R. Krathwohl, Kerangka landasan untuk pembelajaran, pengajaran, dan asesmen. Yogyakarta: Pustaka Pelajar 2010.

[5] S. Bahri, Optimalisasi kinerja kepala sekolah.Jakarta:Gibon Book, 2010.

[6] E. Mulyasa, Menjadi kepala sekolah efektif, Bandung: PT.Rosdakarya: 2013.

[7] D. Daryanto, Adminstrasi pendidikan, Jakarta: Rineka Cipta, 2011 